\title{
1. Editors' introduction
}

\section{Alan Bogg, Cathryn Costello and A.C.L. Davies}

The time seems particularly ripe for the publication of a research handbook on the labour law of the European Union. This relatively young discipline now finds itself at the centre of a whirlwind of powerful economic and political forces, and there is considerable uncertainty as to how it might develop, both in terms of its substantive content and its evolutionary processes. It is therefore an opportune moment to draw together a group of leading scholars of EU labour law to assess the 'state of the art' and to identify research questions for the future. The contributions can be grouped into four broad categories: cross-cutting themes, individual employment law, collective labour law and equality law.

\section{CROSS-CUTTING THEMES}

Our volume begins with two chapters assessing the relationship between EU labour law and national law. Chapter 2, by Phil Syrpis, gives an overview of the EU's treaty framework, noting the importance of the changes brought about by the Treaty of Lisbon, and inviting deeper reflection on whether these changes have served in practice to increase the importance of the EU's social goals relative to the economic freedoms. He then turns to the EU's competences in the field of labour law. Although these competences are limited in significant ways, he argues that surprisingly little use has been made of them to develop strong social protection for workers. Again, this may be because of the tension between the economic and the social. Syrpis then draws out an important theme for many of our contributors: the relevance of EU labour law to other bodies of EU law, including human rights law, the law of the internal market, and the governance arrangements for the Eurozone. Although human rights law has the potential to bolster the social dimension of EU law, Syrpis points to some of its limitations, including the problematic distinction between rights and principles (examined in more detail by Busby in Chapter 7) and the potential for employers to assert countervailing rights, as highlighted by the Alemo-Herron ruling. ${ }^{1}$ Internal market law has the potential to threaten the autonomy of Member States to set high social standards because it may be argued, as it was in the Viking and Laval cases (also explored by Barnard in Chapter 14) that such standards infringe employers' economic freedoms and may only be maintained in force where they can be justified under a

1 Case C-426/11 Alemo-Herron v Parkwood Leisure Ltd ECLI:EU:C:2013:521. 


\section{Research handbook on EU labour law}

proportionality test. ${ }^{2}$ Finally, Syrpis notes the impact of the increasingly strict Eurozone governance mechanisms on national labour law systems, driven as they are by the highly controversial assumption that labour law distorts markets, a point developed more fully by Koukiadaki in her chapter on the financial crisis. Overall, Syrpis's chapter serves to highlight the challenges facing EU labour lawyers at this point in the subject's history: to grasp the full range of ways in which national labour law may be affected by the activities of the EU and to mount a robust defence of the place of the social within the EU's legal and political frameworks.

The relationship between EU law and national law is the central theme of Prassl's contribution in Chapter 3. He begins with an examination of the doctrines of direct effect and supremacy as developed by the Court of Justice. The orthodoxy is that direct effect serves to 'embed' EU law within national legal systems, while supremacy ensures that conflicts between EU law and national law are always resolved in favour of EU law. Prassl notes that the radical consequences of these doctrines are, in theory at least, somewhat mitigated by the possibility that Member States might be permitted to justify certain infringements of EU law, or to enact higher standards of social protection in national law and, of course, by the seemingly obvious point that where the EU has no competence, there should be no interaction with national law. He then goes on to explain how, in relation to national labour law, these mitigating factors have not been allowed to operate to any great extent. As the Viking and Laval cases illustrate, the absence of EU legislative competence in a particular area - such as the right to strike does not preclude scrutiny by the Court from an internal market perspective, with little scope afforded to arguments attempting to justify the industrial action in question. The possibility of treating EU labour law as setting minimum standards on which Member States can build has also been threatened by the Court's rulings in recent years, most obviously in the Alemo-Herron case. Taken together, these developments suggest a particularly powerful role for EU law in overriding national autonomy and ensuring uniformity in the field of labour law. However, Prassl strikes an important cautionary note in the remainder of the chapter, by pointing out how diverse national systems of labour law remain in practice. Drawing on research on the impact of the Viking and Laval decisions in different Member States, he contrasts what we might term the 'EU' perspective that these are highly influential cases with their varying effects in a selection of national legal systems, from profound in Sweden to irrelevant in Poland. As Prassl argues, the interaction between EU law and national law offers ample scope for future research.

Perhaps the most obvious contemporary issue affecting EU labour law is the global financial crisis, which resulted in severe economic turmoil in many Member States. This is explored in Chapter 4 by Koukiadaki, and alluded to in others, such as that of Strauss on pensions. As Koukiadaki explains, the crisis affected both the content of national labour law and the process by which the EU influences national labour law. Those Member States seeking 'bailout' funding from the EU and the International Monetary Fund (IMF) were offered the money on condition that they made changes to

2 Case C-438/05 International Transport Workers' Federation v Viking Line ABP [2007] ECR I-10779 and Case C-341/05 Laval v Svenska Byggnadsarbetareförbundet [2007] ECR I-11767. 
national laws and policies, including deregulating their labour markets with measures such as reducing job security, limiting the role of collective bargaining, cutting the minimum wage, or increasing the normal retirement age. This form of labour law development raises a number of concerns. One is that it is heavily driven by a particular policy agenda: that labour legislation is a hindrance to job creation and that deregulation is the solution to the problem of high levels of unemployment. This policy agenda is, of course, hotly contested and does not necessarily reflect the views of democratically elected national governments. Although there are opportunities to examine changes in national law in response to bailouts, such as when legislation is put before national parliaments or challenged in national constitutional courts, this scrutiny may be constrained by the urgent need for bailout funding which may be put in jeopardy if reform proposals are rejected. Although the worst of the crisis is now over, the EU continues to examine Member States' social policies quite closely in the context of more rigorous budgetary scrutiny, particularly within the Eurozone. Koukiadaki explores the possibilities for, and problems with, legal challenges at EU level to the social aspects of the bailout conditions and related interventions, noting, in particular, the potential role of the EU Charter of Fundamental Rights. She offers a powerful argument for the development of a comprehensive litigation strategy including complaints to the International Labour Organisation (ILO) and the European Committee on Social Rights as well as references to the Court of Justice. Her chapter points up the need to reassert the social dimension of the EU project as the Member States emerge from the crisis and to re-engage a wider variety of EU actors, including the social partners, in assessing the impact on workers of economic policy measures.

Another significant challenge to EU labour law is the gridlock within the EU's legislative process in relation to social policy, in particular. It has become increasingly difficult for the Commission to secure agreement in the Council on the enactment of new labour law directives, a case in point being the Working Time Directive, discussed in depth by Bogg in Chapter 12.3 It is widely accepted that the Directive requires revision, but there is no consensus on the direction of reform. There are few new legislative proposals, and as Costello notes, where there are new labour standards, they tend to be developed in other ways, for example, through EU migration law, which is an important source of labour standards for some classes of migrant workers. In general, the Commission's main focus seems to be on the re-examination of the existing acquis through the 'REFIT' programme, a wider scheme to rationalise EU law that extends beyond the field of labour law. ${ }^{4}$ Not surprisingly, many labour lawyers fear that 'rationalisation' may be a euphemism for deregulation.

One alternative to the legislative process as a means of developing EU labour law is, of course, the social dialogue. However, it has also proved difficult to make progress here, revealing the interconnectedness between this process and the legislative process. In Chapter 5 Dukes and Cannon identify three phases in the evolution of the social dialogue. In the first phase, from 1992 to 2002, the social dialogue was closely tied in with the activities of the other EU institutions, with negotiations being initiated by the

3 Council Directive 93/104/EC of 23 November 1993 concerning certain aspects of the organisation of working time [1993] OJ L307/18.

4 Commission, EU Regulatory Fitness (COM(2012) 746 final). 


\section{Research handbook on EU labour law}

Commission and the results being enacted by means of directives in most cases. In the second phase, from 2002 to 2010, there was a greater emphasis on autonomous social dialogue, with the social partners themselves taking more of a lead in initiating negotiations, particularly at the sectoral level, and producing agreements for autonomous implementation through national bargaining mechanisms. Although the outputs of the guided dialogue, such as the Parental Leave Directive, have been criticised for being insufficiently worker-protective, Dukes and Cannon suggest that they did at least have some impact on national law, in contrast to the outputs of the autonomous social dialogue, which had a tendency to vanish without trace. ${ }^{5}$ The authors also identify examples of the social partners' inability to reach agreement in some cases, notably on European works councils and on the information and consultation of employees. This leads neatly to the third phase of evolution, from 2010 to the present, characterised largely by disagreement (for example, on reforming the Working Time Directive) and inactivity, and a corresponding marginalisation of the social partners by the EU institutions. Dukes and Cannon identify a number of problems with the social dialogue: the power imbalance between the European Trade Union Confederation (ETUC) and the employer organisations, the obvious limitations of bargaining in the shadow' of the legislative process when the legislative process is itself inactive, and the absence of a strong social partner infrastructure in many Member States. Moreover, the financial crisis has made it more difficult than ever to develop solidarity among groups of workers in differently situated Member States. Dukes and Cannon then draw attention to the relatively recent emergence outside the EU social dialogue framework of 'transnational company agreements' (TCAs) between European employers and trade unions and addressing a wide variety of different topics. They note their uncertain place in the EU policy agenda and the ongoing disagreement between unions and employers' associations as to whether TCAs should remain voluntary or should be located in some kind of EU-wide legal framework.

In these turbulent times, the Court of Justice has proved to be one of the main sources of new developments in EU labour law. The editors offer an overview of the Court's role in EU labour law in Chapter 6. We identify two phases of development. In the first phase, from the early 1970s to the late 1990s, the Court was at the centre of most developments in EU labour law. Through a series of key decisions in equality law and other areas of labour law, the Court sought to give maximum effect to EU law. For example, by giving direct effect to Article 119 on equal pay in Defrenne, the Court significantly expanded the possibility for litigants at the national level to bring test cases pushing out the boundaries of EU equal pay jurisprudence, prompting action by other EU institutions, particularly in the form of legislation, and challenging national governments' inaction on gender equality issues. ${ }^{6}$ In the second phase of development, from 1999 onwards, there were some significant developments giving greater 'backbone' to EU labour and equality law, including the promulgation of the EU Charter of Fundamental Rights and the enhancement of the EU's competence to enact equality directives under the Treaty of Amsterdam, resulting in the enactment of the Framework Directive and the Race Directive. The Court's use of the Charter was tentative at first,

5 Commission, Industrial Relations in Europe 2010 (2011), 186-187.

6 Case 43/75 Defrenne v SABENA [1976] ECR I-455. 
but expanded significantly once the Charter was given legal effect by the Treaty of Lisbon in 2009. But an account of this phase in the Court's history would not be complete without reference to the emergence through cases such as Viking, Laval and Alemo-Herron of a clearer picture of the hierarchy of norms in EU law. Although the Court is now ready to recognise fundamental human rights, they have not displaced the economic freedoms of the internal market at the top of the hierarchy, with significant consequences for both EU and national labour law. We offer a critical account of these developments, considering the legitimacy of the Court as an actor in the field of labour law and its strengths and weaknesses as a human rights court. We conclude with an assessment of the prospects for the future, noting the challenges the Court faces in regulating newer forms of EU activity, such as bailouts (picking up on themes from Koukiadaki's chapter), and the issues surrounding the EU's proposed accession to the European Convention on Human Rights (ECHR) and the Court's Opinion 2/13 (explored further by Eeckhout and Mantouvalou in Chapter 8).

An in-depth analysis of the EU Charter of Fundamental Rights is provided by Busby in Chapter 7. She explains the history of the Charter and offers a critical account of its 'horizontal' provisions in Articles 51 to 54, which have played and are likely to continue to play a crucial role in determining the Charter's place in EU law and its relationship to the ECHR. She highlights some of the interpretive problems with the Charter, including the uncertain distinction between rights and principles and the lack of clarity surrounding the effect of Protocol 30, dealing with the application of the Charter's solidarity provisions in the UK and Poland. From a labour law perspective, she notes that a particularly significant feature of the Charter is its inclusion of social rights on an equal footing alongside civil and political rights. However, since the Charter does not create new legislative competences for the EU, its practical impact on EU and national labour law will depend fundamentally on how the Court gives effect to it through its jurisprudence.

In addition to giving legal effect to the EU Charter, the Treaty of Lisbon also envisaged the EU's accession to the ECHR. This possibility acquired particular piquancy for labour lawyers because of the European Court of Human Rights (ECtHR)'s developing jurisprudence on collective bargaining and the right to strike through cases such as Demir and Enerji. ${ }^{7}$ It held out the prospect that the Court of Justice's troubling rulings in Viking and Laval might have to be reconsidered in light of the ECtHR's recognition of the fundamental importance of the right to strike to the effectiveness of trade unions in protecting their members' interests. However, the EU's accession negotiations were brought to a sudden halt by the Court's Opinion 2/13, in which it expressed concern that the autonomy of EU law could not be maintained within the proposed arrangements. ${ }^{8}$ The chapter by Eeckhout and Mantouvalou presents a strong case for the EU's accession to the ECHR in terms of the EU's accountability for compliance with human rights. They note that while it is possible to read the Opinion as, in effect, saying that the EU should only accept human rights to the extent that they do not interfere with the EU's own policy priorities, an alternative,

7 Demir v Turkey (2009) 48 EHRR 54; Enerji Yapi-Yol Sen v Turkey, unreported, judgment 21 April 2009.

8 Opinion 2/13 ECLI:EU:C:2014:2454. 
more conciliatory interpretation is both possible and desirable. On their reading, the EU's policy priorities, like the economic freedoms within the internal market, can be seen as legitimate public interests that may justify limiting qualified rights, such as Article 11 ECHR. This would enable the EU's concerns to be taken into account (though of course not necessarily prioritised) within the ECtHR's normal reasoning process. They argue that the EU should be willing to subject itself to the ECtHR's scrutiny, and that the ECtHR can be entrusted with the task.

The potential impact of the ECHR on labour law is deep but not broad. It is highly relevant to some aspects of the subject, such as freedom of association, but as a statement mainly concerned with civil and political rights, it leaves many areas of labour law untouched. These gaps are, of course, filled by the European Social Charter (ESC), but this attracts much less attention in the public and even legal discourse. In Chapter 9, O'Cinneíde explains the evolution of the ESC. He examines the original ESC of 1961, a treaty at once radical, in terms of its identification of social rights, and limited, in that it allowed signatory states some leeway to pick and choose amongst its provisions. He considers the changes brought about by the revised ESC of 1996, which significantly expanded and modernised the list of rights and introduced the collective complaints procedure. Although the collective complaints procedure has proved to be a useful technique for interpreting and monitoring the Charter, the 1996 revision has not been an unqualified success. Ten states have refused to ratify it, preferring instead to remain bound by the 1961 treaty, and a majority of ratifying states still refuse to accept the collective complaints procedure. But perhaps the most significant worry for the ESC regime is its relationship to the EU, described by O'Cinneíde as the "big beast" of socio-economic legal regulation' in Europe. Although there are some references to the ESC in the treaties and in case-law, its impact has been limited. There are two major contrasts between the EU/ESC and EU/ECHR relationships. One is that when a provision of the EU Charter of Fundamental Rights overlaps with a provision of the ECHR, the Court of Justice is obliged to have regard to the ECtHR's jurisprudence. But there is no obligation to have regard to ESC materials where there are overlaps between the Charter and the ESC. Another is that the European Committee of Social Rights does not have any equivalent of the Bosphorus presumption applied by the ECtHR. ${ }^{9}$ The Committee regards social rights as fundamentally under-developed in EU law and is perfectly prepared to find that measures permitted or even required by EU law are not compatible with the ESC. These two contrasts have led to calls for closer integration between the two systems. Although O'Cinneíde regards the most obvious method of integration, the accession of the EU to the ESC, as highly unlikely, for both practical and political reasons, he suggests that a dialogue between the two systems might emerge in the future if the Court of Justice showed a greater willingness to refer to the ESC when interpreting the social rights in the EU Charter. This, he suggests, might help to strengthen the protection of the social in EU law.

A common thread throughout these opening chapters is the need to defend and strengthen the European Social Model. This need has become particularly acute as a result of the financial crisis, in which there was a marked tendency to resort to a simplistic argument from neoclassical economics that labour standards are a burden on

9 Bosphorus Airways v Ireland (2006) 42 EHHR 1. 
business and a hindrance to job creation. One obvious way to do this is by 're-basing' the European Social Model on fundamental human rights, given the many overlaps between instruments such as the ECHR, the ESC and the EU Charter. However, as we have seen, the picture that emerges is a complex one. In the hands of the Court of Justice, fundamental rights may not be placed at the top of the hierarchy of legal norms, given the centrality in the treaty architecture of internal market law and the economic freedoms it protects. This concern with the special nature of EU law has given rise to strong claims about its 'autonomy' and the need to shield it from external scrutiny, exemplified by Opinion 2/13. Discussions of the strengths and weaknesses of a fundamental rights approach to labour law (an issue on which the contributors take a variety of different perspectives) will recur repeatedly in later chapters of this handbook.

The debate about the relationship between EU labour law and human rights law is part of a broader set of trends in which it is becoming clear that the boundaries of EU labour law are highly porous. As we have seen, EU labour lawyers no longer confine themselves to a study of provisions formally identified in the TFEU as the EU's labour law competences. They must be experts in understanding not only human rights law but also the relevance of internal market law, the rules on Eurozone governance, and the conditions attached to bailouts, if they are to grasp the full range of places in which the EU 'does' labour law. Although the remaining chapters in the collection take as their central focus the directives and jurisprudence making up the core of EU labour law, focusing as they do on familiar topics in individual employment law, collective labour law and equality law, all the contributors have an eye to the broader context. Discussions of relevant ECHR provisions, or the role of the EU's economic governance mechanisms, are now commonplace. In this respect, we hope that the collection illustrates the richness of EU labour law as a field of scholarly enquiry.

\section{INDIVIDUAL EMPLOYMENT LAW}

One of the central problems in labour law systems across the European region is the position of the 'standard employment relationship' in law and practice. The 'standard employment relationship' typically envisages a bilateral, full-time and open-ended contractual arrangement with a single employer, with work undertaken at the employer's premises. It is undeniable that the 'standard employment relationship' has been the central organising concept of labour law in member states, and it has generally served three main functions: descriptive, normative and legal-institutional. Sometimes the concept is deployed as a descriptive tool that identifies 'standard' employment as statistically typical in a labour market. It is thus a kind of heuristic device that enables lawyers and sociologists to identify a particular set of work arrangements as a general standard in employment practices. It may also perform a normative function in identifying 'standard' employment as an ideal that instantiates important values such as stability, security and reciprocity. ${ }^{10}$ Typically, this is reflected in the allocation of job

10 M Freedland and N Kountouris, The Legal Construction of Personal Work Relations (OUP 2011). 


\section{Research handbook on EU labour law}

security rights to employees in standard employment, and the contrasting absence of job security being a strong marker of precariousness in non-standard work arrangements. Finally, it may perform a legal-institutional function in serving as a platform that links legislative protection for employees with reciprocal responsibilities under the revenue regime to account for tax and national insurance. The effect of this may be to create an exclusionary boundary or 'binary divide' which separates the labour market into privileged 'insiders' and precarious 'outsiders' to worker-protective norms.

As non-standard forms of work have proliferated in labour markets, the position of the 'standard employment relationship' has come under increasing scrutiny. Its utility as a descriptive tool has been questioned, as non-standard work has grown in statistical significance in European labour markets. In tandem with this, political and economic ideologies contest the centrality of its role as a normative and legal-institutional concept. Unsurprisingly, these debates have been as vigorous in European labour law as in national labour law systems. The analytical and normative controversies around the life/death/resurrection of the standard employment relationship provide the broad theoretical frame within which the chapters on individual labour law may each be located.

In Chapter 10, Davies examines the interaction between 'job security' and 'flexicurity' in the theory and practice of European labour law. In so doing, she draws attention to the nuances within these concepts. The animating ideal of European labour law in the last two decades has been the concept of 'flexicurity'. While this terminology is politically contested, it has been aligned with a discourse that emphasises reductions in job security, high levels of training to enable workers' capacities to be adaptable in labour markets, a generous social security net and encouraging flexible patterns of work. Rhetorically, at least, it represents an alternative both to market deregulation and to strongly worker-protective norms of job security. Davies examines the extent to which this rhetoric has been translated into the structures and techniques of European labour law. In so doing, she analyses the directives regulating economic dismissals and transfers of undertakings; the directives regulating 'atypical' work in the contexts of part-time, fixed-term and agency work; and recent activity in the soft-law methods of the Open Method of Coordination in the wake of the financial crisis. What she detects is a decisive shift towards a deregulatory discourse, particularly in post-crisis developments.

While the non-discrimination paradigm in the atypical work directives has often not achieved a 'levelling up' of non-standard workers' working conditions, recent activities under the Open Method of Coordination have encouraged deregulation of the 'standard employment relationship' in some member states. While this 'levelling down' certainly reduces the regulatory gradient between standard and non-standard work forms, it is unlikely to do so in a way that ensures decent and secure work for all. Davies nevertheless concludes that 'flexicurity' continues to possess emancipatory potential in its continuing attachment to 'standard employment' as a normative ideal in labour markets. Even if contractual arrangements become more diverse and flexible, the economic coordination, risk sharing, fiscal and regulatory functions of standard employment will still need to be served. In short, if the standard employment 
relationship ceased to exist, 'flexicurity' would need to reinvent it and buttress it in order for 'flexicurity' to be sustainable as a model of labour market regulation. ${ }^{11}$

Kountouris, in Chapter 11, approaches this set of issues from another vantage point, exploring the position of 'atypical' work arrangements in European labour law. While he focuses his attention on the structure and implementation of the directives concerned with fixed-term, part-time and agency work, Kountouris also draws attention to the wider regulatory context of atypical work such as the Posted Workers' Directive and the objectives of the European Employment Strategy. ${ }^{12}$ This set of measures has coalesced around the objective of 'normalisation' of atypical work, encouraging the flexibility of work arrangements and thereby facilitating the disintegration of standard employment. The smoke and mirrors of 'flexicurity', which portrays the trade-offs between flexicurity and security as a virtuous circle for employers, workers and member states, sometimes obscure this dis-integrative process. Kountouris' analysis provides a stark and compelling look at the structural limitations of a regulatory approach which presupposes the value of normalising temporary work. Moving beyond the deconstruction of flexicurity's 'broken promise', ${ }^{13}$ he defends an entrenchment of standard employment under the banner of 'decent work'. This would envisage the utilisation of a range of regulatory tools - equal treatment, specific rights to satisfactory working conditions, non-abuse norms to tackle specific abuses of atypical work forms - to address the multiple sources of precariousness in atypical work. Significantly, this would also permit member states to reintroduce administrative restrictions on undesirable forms of atypical work, reflecting a judgement that disadvantage is intrinsic to (rather than simply contingently associated with) certain forms of atypical work. From a worker-protective perspective, and in contrast to Davies, the flexicurity paradigm would appear to be a lost cause for Kountouris. His rejection of flexicurity reinvigorates the case for a European universal 'floor of rights' for all those engaged in the activity of paid work, whether in formal or informal labour markets. This also discloses a strong normative attachment to the 'standard employment relationship' as the relational centre around which the circumference of labour law is drawn.

These themes also recur in Bogg's chapter on the European regulation of working time. The Working Time Directive (WTD) has been highly influential in configuring the regulatory problems associated with working time around the health and safety challenge of excessive and uninterrupted working periods. ${ }^{14}$ To this end, the Directive implements norms focused on limiting excessive working hours and guaranteeing daily, weekly and annual rest periods. Bogg argues in Chapter 12 that this perspective on the regulatory significance of time in work is unduly limiting. Time is central to the architecture of the standard employment relationship. Duration provides only one dimension of significance and measurement, however. Time may be measured in terms

11 See also Zoe Adams and Simon Deakin, 'Institutional Solutions to Precariousness and Inequality in Labour Markets' (2014) 52 Brit J Indus Rel 779.

12 Directive 96/71/EC of the European Parliament and of the Council of 16 December 1996 concerning the posting of workers in the framework of the provision of services [1997] OJ L18/1 ('PWD').

13 S Fredman, 'Women at Work: The Broken Promise of Flexicurity' (2004) 33 Indus LJ 299.

14 PWD (n 12). 
of its predictability and stability; it may be measured in terms of its quality (how intense and monotonous are working tasks); and it may be evaluated in terms of its structuring, scheduling and organisation by employers. After the financial crisis, work arrangements have been characterised by an explosion of regulatory problems associated with time and precariousness: highly casualised employment relationships where time is unstable and unpredictable; involuntary short-time working; excessive hours working in new and precarious forms of self-employment; and the hyper-flexibilisation of work organisation and scheduling. Any reform of the WTD must address these diverse regulatory problems. It is also important to scrutinise the regulatory benefits of the Court of Justice of the European Union (CJEU)'s development of a rich fundamental rights jurisprudence under the WTD. Thus far, the promise of fundamental rights remains unfulfilled for workers engaged in highly casual and precarious forms of employment. Unless working time reform is located at the very centre of any regulatory strategy to address precariousness, the true significance of working time norms in supporting or corroding the stability of the standard employment relationship will be missed.

Costello, writing in Chapter 13, sets out to provide an overview of the implications of EU mobility and migration status for labour law, drawing on the insights of her edited collection with Mark Freedland. ${ }^{15}$ The chapter's broad purpose necessitates a broad-brush overview of the various migration statuses regulated in EU law, particularly their implications for labour rights. The chapter examines EU citizenship, posted workers and the patchwork of migration statuses created by EU law, under the Single Permit Directive, for Students, Researchers, Highly Skilled Workers (Blue Card Directive), Seasonal Workers and Intra-Corporate Transferees. ${ }^{16}$ The position of irregular migrants is also considered, under both the EU Employer Sanctions Directive and the potentially highly significant ruling of the Court of Justice in Tümer. ${ }^{17}$ The processes whereby migration status creates risk factors for labour exploitation are explored, and a research agenda thereby opened up for labour lawyers. Doctrinally, she notes that the commitment in Article 15(3) of the Charter to equality in working conditions for regular third-country national (TCN) migrants with EU Citizens is in tension with many laws and practices at present. Its equal treatment guarantee sits uneasily with the stratification of rights institutionalised in EU (and indeed domestic) migration status. She also suggests that migration statuses may also perpetuate discrimination on other prohibited grounds. The chapter suggests that some vulnerability to exploitation is, at least in part, legally constructed in migration status. This suggests reforming immigration law is warranted. However, if that move is politically unlikely, other sources of protection need examination. There appears to be a tendency

15 C Costello and M Freedland, Migrants at Work: Immigration and Vulnerability in Labour Law (OUP 2014).

16 Directive 2009/50/EC on the conditions of entry and residence of third-country nationals for the purposes of highly qualified employment [2009] OJ L155/17; Directive 2014/36/EU on the conditions of entry and stay of third-country nationals for the purpose of employment as seasonal workers (Seasonal Workers Directive) [2014] OJ L94/375; Directive 2014/66/EU on the conditions of entry and residence of third-country nationals in the framework of an intracorporate transfer (Intra-Corporate Transferees Directive) [2014] OJ L157/1.

17 Case C-311/13 Tümer ECLI:EU:C:2014:2337. 
to focus on criminalisation, particularly through severe labour exploitation, as a recent Report by the EU Fundamental Rights Agency exemplifies. ${ }^{18}$ Further doctrinal and empirical work on these phenomena is warranted.

\section{COLLECTIVE LABOUR LAW}

In relation to collective EU labour law, the debates tend to be framed around a different set of concerns. Labour law scholars have examined the position of trade union rights in the European legal order; the role of the Court in its adjustment of trade union rights against the employer's free movement rights under the EU treaties; and the extent to which the mechanisms and institutions of 'collective voice' are underpinned by an effective legislative framework at the European level. In a brave undertaking, Barnard provides an overview of the scholarship that emerged out of the Viking and Laval litigation. ${ }^{19}$ Is there anything new or original capable of being said given the ink that has now been spilt on this most important topic? The editors were mindful of the enormity of the task presented to the author. In our view, Chapter 14 provides a thought-provoking and innovative perspective on the methodological state of European labour law, using Viking and Laval as the context for examining different stages of scholarly response. In so doing, she affirms the richness of the scholarly endeavour in the field, while also identifying specific ways in which a more explicit engagement with methodology and empiricism would be valuable. This would resurrect the historic alignment between labour law and highly empiricist industrial relations scholarship that British students of labour law would be very familiar with. There is also a strong sense from Barnard's chapter that research should be regarded as a collegial endeavour amongst scholars working in a spirit of collaborative respect. Academic norms of pluralism and free enquiry anticipate a range of methodologies suitable to particular research questions. A diverse mix of high quality legal, philosophical, normative and empirical studies enables scholars to advance the boundaries of their discipline. It is a shared endeavour, and it is thus a shared responsibility. It reflects a deep attachment to solidarity that is, alas, missing from the judgments in Viking and Laval themselves.

In Chapter 15, Njoya provides a powerful analysis of the directives protecting worker voice through consultation and participation at the EU level. In so doing, she examines the dilemmas of autonomy and subsidiarity in implementing institutional mechanisms for worker voice, given the significant diversity of worker representation models in different member states. Given the identification of the right to information and consultation in the EU Charter, ${ }^{20}$ what is the appropriate balance between reflexivity and fundamental rights in the sensitive area of worker participation? Njoya acknowledges the regulatory difficulty - it is perhaps the central regulatory difficulty of

18 FRA, Severe Labour Exploitation: Workers Moving within or into the European Union (FRA, June 2015).

19 Viking (n 2); Laval (n 2).

20 Art 27 of the Charter of Fundamental Rights of the European Union. 
transnational collective labour law - and she explores the value (and limits) of reflexivity in this regulatory context. What is striking in her analysis is the patchiness of European labour law, and the large regulatory gaps in minimum EU standards on freedom of association, collective bargaining and the right to strike. It should be recalled that these norms are also recognised as fundamental rights under the EU Charter, yet this is not reflected in the legislative landscape, given the significant limitations on EU legislative competence in this area. Yet without an interlocking set of collective norms and institutions, whereby distributive conflicts are channelled through collective bargaining so as to open up regulatory space for consultative cooperation, the consultation and participation directives are unlikely to be effective in realising the fundamental rights underpinning 'industrial democracy'.

Indeed, Njoya's concern with the 'gappiness' of European labour law touches upon wider themes that run across all of the substantive chapters on individual and collective labour law. Is it possible for European regulation of working time to be coherent without European regulation of pay? Is it possible to support the standard employment relationship as an institutional mechanism without a specific measure regulating job security in member states? Can one regulate atypical work effectively without a specific instrument to regulate 'zero hours' and other forms of 'casual' contractual arrangement? What happens if we constitutionalise free movement rights whilst offering only weak legal protection to workers' collective labour rights? In short, given the gaps in European labour law attributable to European realpolitik and circumscribed legislative competence, is a coherent European labour law possible? Certainly, alignment with a 'decent work' paradigm, which presupposes a universal platform of integrated social rights, seems difficult to reconcile with the current patchwork state of European labour law.

\section{EQUALITY}

The chapters that comprise the equality part of the Handbook reflect the distinctive trajectories within EU equality law. As is well known, EU equality law has its origins in the 1957 Treaty guarantee of equal pay for men and women, with a wider commitment to gender equality coming later. While non-discrimination on grounds of nationality is an important aspect of the internal market and EU citizenship, it does not protect third-country nationals in the same way. Beyond sex and nationality, the Treaty of Amsterdam was the watershed in the evolution of EU equality law, granting the EU competence to combat other forms of discrimination. On that basis, the EU enacted two main directives in 2000, one on race and ethnicity discrimination, with broad scope, and the Framework Directive on grounds of religion or belief, disability, age and sexual orientation confined to employment and occupation. ${ }^{21}$ As was noted above in relation to general EU labour law, since then significant legislative reform has not been forthcoming. The Commission proposed a wider directive in 2008, which would extend

21 Directive 2000/78/EC establishing a general framework for equal treatment in employment and occupation OJ L 303/16; Directive 2000/43/EC implementing the principle of equal treatment between persons irrespective of racial or ethnic origin OJ L 180/22. 
the prohibition of discrimination on grounds of religion or belief, disability, age and sexual orientation to social protection, social advantages and education as well as access to and supply of goods and services available to the public, including housing. ${ }^{22}$ The contributors all regret that it has not yet garnered sufficient political support. Notably, although the contributors were invited to focus on labour law, they assume that equality in the workplace requires social change, so they examine discriminatory practices outside that context.

Fredman's panoramic Chapter 16 surveys the 'pasts and futures' of EU equality law, in order to assess whether it is progressing towards 'substantive equality'. Substantive equality is posited in a multi-dimensional conception. Drawing on her previous work, she explains that it entails four complementary and inter-related objectives, namely remedying disadvantage; redressing stigma, stereotyping, prejudice and violence against members of protected groups; enhancing participation of under-represented groups, both politically and socially; and changing underlying structures. Indicative cases for transformative gender equality include the boundary between paid and unpaid work (an issue that recurs in Strauss's chapter on pensions) and the legal regulation of fathers' childcare responsibilities. She notes a transformative approach in some CJEU cases, notably Danosa and Roca Álvarez. ${ }^{23}$ On race discrimination, she considers the implications of the ground-breaking recent decision in Nikolova $v$ CHEZ Electricity, which treated as racially discriminatory an 'offensive and stigmatizing' practice of the Bulgarian electricity company. ${ }^{24}$ The company had used particularly visible forms of protection around electricity meters in Roma neighbourhoods. On sexual orientation, too, she notes that in $A C C E P T$, the Court again affirmed the importance of addressing the expressive power of statements to undermine and stigmatise. ${ }^{25}$ On age discrimination, however, she notes limited structural change, a theme that Freedland and Vickers develop further in Chapter 21.

Ashiagbor's chapter examines 'Religion and Equality in Multicultural Workplaces', contrasting human rights and anti-discrimination approaches. In her subtle account, she examines the case-law of the ECtHR, which has evolved considerably. Originally, the ECHR bodies did not find any infringement of religious freedom in cases where employers prohibited workers from manifesting their religion at work: as workers could quit, that was regarded as ample protection of their human right to religious freedom. However, the ECtHR now acknowledges that these cases raise infringements of Article 9 ECHR, and require justification. This 'human rights' approach is contrasted with the 'equality approach' of the CJEU. She notes some actors support the development of a duty to accommodate religious difference, but rejects this proposal, as it could compromise the right to equality of others, in particular LGBT persons. In her view, the

22 Commission, 'Proposal for a Council Directive on implementing the principle of equal treatment between persons irrespective of religion or belief, disability, age or sexual orientation' $\operatorname{COM}(2008) 426$ final.

23 Case C-232/09 Danosa v LKB Lizings SIA [2010] ECR I-11405; Case C-104/09 Roca Álvarez v Sesa Start España ETT SA [2010] ECR I-8661.

24 Case C-83/14 CHEZ Razpredelenie Bulgaria ECLI:EU:C:2015:480.

25 Case C-81/12 ACCEPT v Consiliul Național pentru Combaterea Discriminării ECLI: EU:C:2013:275. 
prohibition on indirect discrimination provides a context to challenge apparently neutral exclusionary practices, without the need for specific accommodation duties.

Solanke proposes a 'Method for Intersectional Discrimination in EU Labour Law' in Chapter 18, tracing the 40-year history of the legal concept of 'intersectionality'. She distinguishes between 'multiple discrimination' (additive/cumulative) and intersectional discrimination, which she proposes as a disruptive, synergetic strategy. ${ }^{26}$ The method proposed builds a conceptualisation of stigma, in particular 'structural stigma', a concept attentive to historical disadvantage in changing labour market structures. The chapter traces the roots of intersectionality discourse in critical race theory in the United States. In contrast, Solanke notes Europe's discomfort with 'race' as a construct. She suggests that as America replaces class with the 'American Dream', Europe substitutes 'ethnicity' for race. She criticises this move as ahistorical and liable to obscure the nature of disadvantage. She notes that some cases of discrimination against Muslim women have examined headscarf bans as direct religious and indirect gender discrimination, rather than grappling with intersectionality. While multiple discrimination is alluded to in EU directives, intersectionality is not. Like many of the authors in this section, she notes that the two European supranational courts diverge. She finds an intersectional approach in the ECtHR ruling in BS v Spain, but not, as yet, before the CJEU. ${ }^{27}$ Yet, as she admits, the CJEU was attentive to social stigma in CHEZ. ${ }^{28}$ The second element of her methodology for intersectionality is empirical - social scientific research is needed to illustrate patterns of stigma and disadvantage.

On disability discrimination, Fredman notes the striking impact of the UN Convention on the Status of Persons with Disabilities, the focus of the contribution of Lawson and Waddington in Chapter 19, 'The Unfinished Story of EU Disability Nondiscrimination Law'. The EU played an active role in negotiating the Convention and has ratified it. The EU Convention on the Rights of Persons with Disabilities (CRPD) not only signals a clear international commitment to equality for disabled persons, but also a new holistic approach to human rights, transcending traditional boundaries between civil and political and social, economic and cultural rights, and adapting rights to the disability context. The Convention is much wider in material scope than the Framework Directive, but, as the authors note, the extension of the Framework Directive beyond the workplace is now unlikely. However, the Convention may influence other areas of EU law, bringing about a 'creeping mainstreaming of disability non-discrimination requirements'. The most striking impact of the CRPD has been on the CJEU's reinterpretation of the definition of disability in the Framework Directive in light of the Convention, with a significant shift from Chacón Navas to HK Danmark (Skouboe Werge and Ring) decided seven years later in 2013. ${ }^{29}$ Nonetheless, they criticise some features of the newer case-law (despite its ostensible alignment with the CRPD) in particular that it risks excessive focus on the functional limitations of the

26 Iyiola Solanke, 'Infusing the Silos in the Equality Act 2010 with Synergy' (2012) 40 Indus LJ 336.

27 BS v Spain App no 47159/08 (ECtHR, 24 July 2012).

28 CHEZ (n 24).

29 C-13/05 Sonia Chacón Navas v Eurest Colectividades SA [2006] ECR I-6467; C-335/11 HK Danmark (Skouboe Werge) ECLI:EU:C:2013:222. 
victim rather than the acts of the discriminator. Yet to be clarified are the implications of Coleman $v$ Attridge Law, (a 'a high point' for the authors), where the CJEU introduced the concept of discrimination by association. ${ }^{30}$ They argue that Coleman sits uncomfortably with the emphasis, now being placed by the CJEU, on the need for an impairment to hinder a person's participation in professional life. They also assess the case-law on reasonable accommodation and its limiting concept of disproportionate burden, in $H K$ Danmark, finding it broadly satisfactory. ${ }^{31}$ The Court has held that accommodation may require a reduction in working time. Finally, they demonstrate that further research is needed in order to understand the particular barriers to enforcement of rights by disabled persons.

In Chapter 20, Bamforth examines 'Discrimination on the Grounds of Sexual Orientation and Gender Identity', also giving particular attention to the overlapping role of EU and ECHR norms. The chapter considers the development of Strasbourg case-law on the duty to recognise same-sex relationships under Article 8 ECHR. There are some divergences between the ECHR and EU positions on the recognition of same-sex partnerships, with the ECtHR currently taking a more proactive position. On intra-EU free movement, he notes that the EU Citizenship Directive does not treat spouses and same-sex partners equally, instead reflecting a political compromise. ${ }^{32}$ The chapter demonstrates the potential impact of ECHR and EU equality case law on the interpretation of the Citizenship Directive. He concludes with reflections on the diverse pace and trajectory of equality for LGBT persons across the EU Member States, questioning the capacity of EU norms to challenge entrenched social (and often religiously condoned) patterns of discrimination against sexual minorities.

The contribution of Freedland and Vickers on 'Age Discrimination and EU Labour Rights Law' examines three distinct aspects of the right to non-discrimination on grounds of age, namely discrimination against younger workers, discrimination against older workers in general and what they term 'the special case of retirement'. The theme is the extent to which the law demands structural change and how that explains the legal controversies surrounding age discrimination. Notably, while non-discrimination on grounds of age was recognised as a general principle of EU law in the case of Mangold, this has had 'little significance' in their view. ${ }^{33}$ They suggest equality law requires both attitudinal and structural changes, and that frictions around structural change provide an insight into the development of the law. Having assessed the case-law on discrimination against the young and old, and finding some shortcomings, they move to the 'special case' of retirement. The Court has accepted mandatory retirement as serving a number of legitimate aims, including intergenerational solidarity, freeing-up of jobs for younger workers and more contentiously stereotypical assumptions on the decline in performance with age. In general, the Court has given a fairly wide margin of discretion to States in forming labour market policy relating to retirement, reflecting a general reluctance to require deep structural change in the

\footnotetext{
30 C-303/06 Coleman v Attridge Law [2006] ECR I-5603.

31 HK Danmark (n 29).

32 Directive 2004/38/EC on the right of citizens of the Union and their family members to move and reside freely within the territory of the Member States [2004] OJ L158/77.

33 C-144/04 Mangold v Helm [2005] ECR I-9981.
} 
labour market. The reluctance means equality demands may bring unwelcome unintended consequences, as evidenced in the modification of arrangements for retirement. In particular, drawing on the UK experience, they note that there are some indications that limiting mandatory retirement might incentivise employers to limit the duration of their employees' careers through unpalatable means, as shown in Vickers and Manfredi's empirical work. ${ }^{34}$ They conclude that in order to avoid these negative, unanticipated consequences, adopting reasonable accommodation duties in the age context would be desirable, in order to ensure that the aim of ensuring greater inclusion of older and younger workers within the workplace is achieved.

Strauss's contribution on 'Pension Systems and Labour Law in the EU' provides a masterful overview of the complex pension-related processes and institutions of relevance to labour law and changing labour markets. As she notes, the 'perfect storm' of the financial crisis came at a time when national pension systems were already under strain. Chapter 22 opens up a range of new research topics. On labour mobility and the internal market, she examines pension portability and pan-European pension funds. She traces the limited impact of Open Method of Co-ordination (OMC) in this field, and the long road to the adoption of a Directive on pension portability in $2014 .{ }^{35}$ On pension funds, she assesses the marginal effect of the legal measures adopted. ${ }^{36}$ She acknowledges that the social partners' concerns that such funds could be a stalking horse for privatised provision is 'likely not misplaced'.

The chapter's central concern is the inequality of access to pensions, in particular for many young workers, women and migrants. Examining the empirical institutional trends, Strauss analyses how precariousness in work means that even the existence of pension rights cannot be taken for granted. While the EU policy processes cast 'adequacy' and 'sustainability' of pension systems as competing priorities (with most emphasis on the latter), as she demonstrates, access to good jobs is a prerequisite for both. EU equality law has had an impact on pensions, with issues concerning gender, migrant status and age discussed. Yet, at a deeper level, pension systems may replicate labour market segmentation and inequalities in earnings into retirement. They also illuminate the way paid and unpaid work are valued over the life course. Using empirical evidence of the general institutional trends, she demonstrates that higher levels of pensioner poverty and inequality within and between Member States are a likely consequence of current pension reforms.

Across the chapters, there is consensus that equality law involves commitments to substantive equality, but some diverse accounts of what that entails. For instance, in contrast to Fredman's broad conception, which encompasses combatting stigmatisation as one of the four aims of equality, Solanke's approach gives the concept of 'stigma' a distinctive reading. On the scope of duties, the contrast of views on reasonable

34 For evidence of this trend in the Higher Education sector, see S Manfredi and L Vickers, 'Pensioning Off the Mandatory Retirement Age: Implications for the Higher Education Sector' (2013) 33 Legal Stud 289.

35 Directive 2014/50/EU on minimum requirements for enhancing worker mobility between Member States by improving the acquisition and preservation of supplementary pension rights [2014] OJ L128/1.

36 Directive 2003/41/EC on the activities and supervision of institutions for occupational retirement provision [2003] OJ L235/10. 
accommodation is striking. Ashiagbor rejects reasonable accommodation on grounds of religion as liable to privilege religious freedom over the equality of others. In contrast, Freedland and Vickers see reasonable accommodation as a suitable tool to address competing interests and ensure that practices meet the aim of workplace inclusion. Freedland and Vickers see equality law's role in prompting attitudinal change as less demanding than structural change, but Bamforth notes the limits of law in overcoming social prejudice. Strauss's chapter demonstrates that the processes that generate inequality in old age are complex and multifaceted and often escape equality law's purview.

The CJEU remains the main actor in the dynamic development of EU equality law, but across the 'new' grounds, there is considerable overlap with the ECtHR. The contributions variously examine the role of the ECtHR, and points of friction between the CJEU and the ECtHR. For instance, Ashiagbor discusses its case-law on religious freedom in the workplace, Bamforth the cases on recognition of same-sex relationships, and Solanke its limited but important case-law on stigmatisation and intersectionality. The general conclusion on the CJEU's case-law is, perhaps inevitably, mixed, with some praise and some critique. The UN Convention on the Rights of Persons with Disabilities, which the EU ratified in 2009, has a clear, discernible impact on the interpretation of the EU norms, as Fredman notes and Lawson and Waddington examine. However, little reference is made to other international norms (CEDAW or CERD, for example) reflecting the standard assumption that these have not had great impact within the EU system at present. ${ }^{37}$ Fredman identifies a 'strikingly uneven pattern' in the case-law of the CJEU and concludes that too little attention has been paid to structural transformation, a conclusion that resonates throughout the other contributions. Indeed, Freedland and Vickers' explanatory and normative framework suggests that resistance to structural change may account for the diversity of the case-law and its reception.

\section{CONCLUSION}

We hope that the reader will agree with us that this handbook showcases the richness, diversity and depth of current scholarship on European labour law. It is thus a fitting testament to the breathtaking richness and variety of European labour law itself. As many of the chapters have explored in their different contexts, the field is now at a pivotal point in its evolutionary development. Although the high drama of the financial crisis has now receded, the unfolding tragedy of migration across European borders exposes the fragility of the European political project. It is not just the European social model that is under threat. The very idea of European solidarity has been subjected to tectonic pressures not witnessed since the middle decades of the twentieth century.

37 For a discussion on how CEDAW could have an impact, see V Neubauer, 'How could the Convention on the Elimination of All Forms of Discrimination Against Women (CEDAW) be

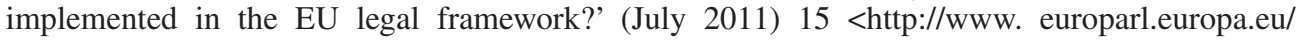
document/activities/cont/201109/20110909ATT26166/20110909ATT26166EN.pdf> accessed 10 January 2016. 
Constitutional values, such as respect for democracy and the Rule of Law in Member States, are under threat once more as political support for far-right political movements has surged across Europe. And substantial uncertainty has been created by the recent referendum vote in the UK in favour of leaving the EU.

This last development, which occurred after the chapters in this volume were written, is of particular significance for our contributors, many of whom are based in the UK and now face the prospect of writing about future developments in EU labour law from the sidelines. Of course, it remains far from clear when and how - or even whether so-called 'Brexit' will take place. Assuming it does, its effect on EU labour law is hard to predict. On the one hand, the UK's departure may remove one of the obstacles to a more strongly social focus for Europe, in the shape of the long-standing opposition of UK governments across the political spectrum to significant new developments in EU labour law. On the other hand, the prospect of a near-neighbour with a substantially deregulated labour market may create downward pressure on labour standards within the EU itself, taking the EU further in the direction of deregulation now seemingly supported by the Commission. Perhaps the most important lesson of the UK's recent experience is the importance of a European social model that is robust and that benefits and is seen to benefit ordinary working people. Those who voted to leave the EU did so for a variety of different reasons, but one significant group of 'leave' voters were those who believed that competition from firms or workers elsewhere in the EU was the cause of downward pressure on their wages or the demise of their industry and consequent unemployment. For this group of voters, any rights afforded by the European social model were clearly outweighed by their experiences of economic decline, recession and austerity. Thus, it should not be thought that these existential challenges diminish the significance of the European social model and its future. On the contrary, we should recall the constitutional bedrock of the International Labour Organisation that 'universal and lasting peace can be established only if it is based upon social justice'. These words, born out of the bitter legacy of world conflict, still carry a potent message. They remind of us of the urgency of the task of labour lawyers as guardians of a disciplinary heritage, with guardianship based upon scholarly values of rigour, toleration, free enquiry and open dialogue, animated by a passionate commitment to the emancipation of human beings. In their different ways, the contributions to this volume live up to these high expectations of scholarly endeavour. The publication of this handbook could not be more timely, given what is now at stake. 